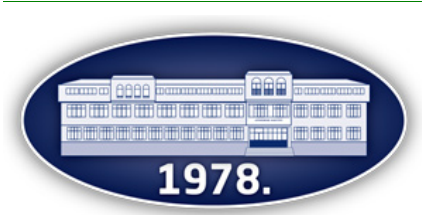
Publisher: Faculty of Agronomy Čačak

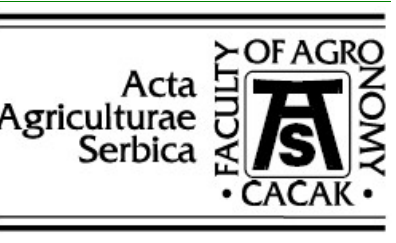

\title{
Organic farming as the basis for the long-term health of the soil ecosystem
}

\author{
Aleksandr M. Semenov ${ }^{1,2 *}$, Dragutin A. Đukić3 ${ }^{3}$ Leka Mandić $^{3}$, Vesna Đurović3, \\ Alexey P. Glinushkin²
}

${ }^{1}$ Faculty of Biology, Department of Microbiology, Moscow State University of M.V. Lomonosov, Leninskie gory, 1/12, Moscow, 119234, Russian Federation

${ }^{2}$ All-Russia Research Institute of Phytopathology, ul. Institut, vlad. 5, r.p. Bol'shie Vyazemy, Odintsovskii r-n, Moskovskaya obl., 143050, Russian Federation

3 Department of Biology and Microbiological Biotechnology, Faculty of Agronomy, University of Kragujevac, Cara Dušana 34, 32000 Čačak, Serbia

*Corresponding author: amsemenov@list.ru

Received 26 April 2021; Accepted 28 September 2021

\begin{abstract}
A B S T R A C T
This study compares and discusses two farming systems that differ in content - organic and conventional (intensive) systems. In this regard, a modern definition of soil content is proposed, with the "soil ecosystem" concept used as the modern alternative to the traditional representation of what the soil is. Some features of the functioning of soil ecosystems in the two different farming systems, conventional and organic, are examined. The inner essence and the external performance of these two alternative land-use systems are revealed. The importance of the development of organic agriculture is emphasized by the documents of international organizations (IFOAM). The tasks that need to be addressed during the transition to a knowledge-intensive system of production of environmentally friendly agricultural products under organic farming conditions are briefly listed. The focus is on those aspects that are important in the transition from intensive to organic farming. The need to introduce a new characteristic of soil ecosystems - soil health - is discussed. A modern definition of "soil health" is given. The positive impact of organic farming and its technologies on soil health is discussed. The list of actions for the continuous maintenance and reproduction of soil health is presented. Much attention is paid to soil health maintenance, remediation and rehabilitation. The problems of protecting plants and crops from harmful organisms in organic farming are discussed. The phenomenon "oligotrophication of agro ecosystems" as an unconventional way of healing and maintaining the health of soil ecosystems is considered and discussed. The thesis about the necessity to consider soil quality and fertility as components of the new characteristic - "soil health" is proposed.
\end{abstract}

Keywords: soil, soil ecosystem, intensive agriculture, organic agriculture, soil health, diagnosis, therapy.

\section{Извод}

У овом раду се упоређују и разматрају два различита система пољопривреде - органски и конвенционални (интензивни) системи. С тим у вези, предлаже се модерна дефиниција земљишта, при чему се концепт „земљишни екосистем” користи као модерна алтернатива традиционалном представљању онога што је земљиште. Испитују се неке карактеристике функционисања земљишних екосистема у два различита система пољопривреде - конвенционалном и органском. Откривају се унутрашња суштина и спољашње перформансе ова два алтернативна система коришћења земљишта. Колики је значај развоја органске пољопривреде показују и документи међународних организација (IFOAM). Укратко су наведени задаци које је потребно решити при преласку на систем производње еколошки прихватљивих пољопривредних производа у условима органске пољопривреде. Фокус је на оним аспектима који су важни у преласку са интензивне на органску пољопривреду. Разматра се потреба увођења нове карактеристике земљишних екосистема - здравља земљишта - потенцирајући нову модерну дефиницију у којој ова карактеризација заузима значајно место. Разматра се позитиван утицај органске пољопривреде и њених технологија на здравље земљишта, уз приказ листа мера за његово континуирано одржавање и репродукцију. Велика пажња се поклања очувању здравља земљишта, његовој ремедијацији и рехабилитацији и проблеми заштите биљака и усева од штетних организама у органској пољопривреди. Разматра се и дискутује феномен „олиготрофикације агроекосистема” као неконвенционалан начин лечења и одржавања здравља земљишног екосистема где квалитет и плодност земљишта заузима значајно место.

Кључне речи: земљиште, земљишни екосистем, интензивна пољопривреда, органска пољопривреда, здравље земљишта, дијагноза, терапија.

\section{Introduction}

In everyday terms, organic farming (synonymous concepts - alternative, sustainable, environmentally friendly, biodynamic, etc.) is the use of a soil ecosystem
(SE) to obtain a high-quality, environmentally friendly harvest, an acceptable volume, without the use of genetically modified organisms (GMOs), synthetic mineral fertilizers and pesticides, excluding some ameliorants (Schjønning et al., 2002 ). According to its 
"ideology", organic farming (OF) is, on the one hand, individual farming, the sphere of activity of an individual producer. At the same time, OF imposes special requirements on such agro ecosystems, minimum scale, location and relationship with neighboring agrosystems, etc. For example, it is impossible to produce an "organic" product in the vicinity of the production of traditional "conventional" products (Glinushkin et al., 2016).

Historically, organic farming as a crop production system is undoubtedly primary. Before the era of awareness and mass production of chemical (inorganic) fertilizers, agriculture was, of course, ubiquitous "organic". However, in the twentieth century, "convention agriculture" became primary "common", "traditional agriculture", in the Russian language literature - intensive, industrial agriculture. It is characterized, firstly, by the massive use of mineral fertilizers - traditional NPK, as well as (if necessary!) $\mathrm{Si}$, $\mathrm{B}, \mathrm{Mg}, \mathrm{Zn}, \mathrm{V}, \mathrm{Mo}$, etc. Secondly, IA is based on the widespread use of pesticides, the negative environmental and hygienic effects of which are well known. Finally, in dozens of countries in the framework of intensive farming today, genetically modified plants that are resistant to harmful arthropods and/or to indiscriminate herbicides (glyphosate, etc.) are widely used.

Let us note some generalized results of long-term observations and experiments on the consequences of convention agriculture. It has been reliably shown that intensive farming leads to a reduction in soil organic matter in a soil ecosystem (SE), and in extreme situations - even to its complete loss. Due to a decrease or even loss of organic matter, as well as due to the biocide action of some pesticides, soil geobionts -for example, ammonifiers and nitrogen fixers - are deprived of a vital nutrient substrate. In this case, the cycle of biophilic elements of the soil ecosystem is interrupted, like the cycle of microorganisms. Intensive (convention) farming in general leads not only to changes, but also to a reduction in biological diversity, intensification of greenhouse gas emissions $\left(\mathrm{CO}_{2}, \mathrm{CH}_{4}\right.$ $\mathrm{N}_{2} \mathrm{O}$ ) from the soil. Since convention farming is often accompanied by long-term monoculture cultivation, the expansion of phytopathogens, phytophages and weeds occurs, which often takes on the character of epidemics and invasions (Van Bruggen and Semenov, 2015; Veličković et al., 2016; Đukić et al., 2020).

\section{Requirements and conditions for farming in the transition to organic farming}

It is a mistake to believe that simply abandoning the use of synthetic agrochemicals and GMOs will allow you to immediately switch to organic farming. Far from it. First, the land user must be convinced of the need to constantly follow the principles of $\mathrm{OF}$ and be prepared for a number of costs associated with its technologies.

Secondly, a certain transitional period will be required, during which "organic products" (crops produced using organic farming technologies, following more stringent environmental and hygienic standards) will meet the required quality.

Thirdly, the land user will need versatile knowledge about the bioecological foundations of the complex of processes occurring in the soil ecosystem (operated according to the OF system). New knowledge will also be needed to optimize the nutritional regime of cultivated crops, to master new technologies for the prevention and containment of the development of harmful organisms (Van Bruggen et al., 2006).

In addition to the need to fulfill the listed requirements for the long-term maintenance of the productivity of organic agroecosystems (AES), it is necessary to have practical decisions on the selfprovision of such systems with nutrients for the functioning of useful biota, on the "control" of phytopathogens and phytophages of subsurface and above-soil ones in such AES, control of weed and harmful plants, and methods of treatment of "organic" nuclear power plants. The issues of "therapy" for such soil ecosystems remain the most difficult to resolve (Spiridonov et al., 2019).

\section{The environmental benefits of organic farming}

The importance of organic farming is elevated to the international level. The International Organization for Organic Agriculture (IFOAM) has defined OF as a production system that ensures the health of soils, ecosystems and humans based on natural, locally adapted, environmentally balanced processes and safe sources of soil organic matter enrichment. OF ensures the harmonization of the circulation of substances and energy, supports biodiversity, optimization of the competitiveness of cultivated plants against weeds, diseases and pests, with a complete rejection of the use of pesticides and GMOs (Organic regulations. URL: http://www.ifoam-eu.org/en/what-we-do/organicregulations).

In the process of organic farming, the concentration of organic matter in the soil is initially restored, and subsequently it even increases (Franzluebbers et al., 1995). In such soil, the amount of readily available forms of nitrogen decreases, but its total content increases. Taxonomic and functional soil biodiversity increases (Garbeva et al., 2004; Madder et al., 2002), the proportion of microbial biomass and its activity increase, primarily the number of nitrogenfixing bacteria and mycorrhizal fungi (Drury et al., 1991). The mechanical structure of the soil, its aggregate composition, water retention capacity and cation exchange capacity change and improve. All this, in turn, contributes to the development of soil mesofauna (Ferris and Tuomisto, 2015). In general, the soil in agroecosystems with OF is most consistent with healthy soil (Semenov and Sokolov, 2016; Semenov et al., 2011; Sokolov et al., 2015).

Historically, in the transition from intensive to organic farming, several ecological and technological stages can be noted (Buyer, Kaufman, 1996). The most noticeable step is the emergence and spread of "low input" agricultural technology, which involves the reduction, limited use of, first of all, mineral fertilizers, and even the "reasonable" use of organic fertilizers (Clark, 1999). Of course, these "limited" levels of mineral fertilizers in absolute terms are different for different countries and climatic zones. However, it was from this very beginning that the ideology of the "sustainable development of agriculture" was implemented, during the implementation of which there was a gradual transition to the use of predominantly organic fertilizers in combination with the mobilization of natural, self-sustained soil fertility (Sustainable Development Strategy, 2002). 
To maintain effective soil fertility and quality, it is allowed to apply manure, composts and various organic fertilizers, if such fertilizers are produced on farms that have switched to the $\mathrm{OF}$ system. The sale of products of the corresponding true organic farming system is possible only after the end of the transition period, which lasts at least 5-6 years, subject to strict observance of the requirements and rules of IFOAM and certification. In the OF system, problems and tasks that arise have to be solved taking into account the limitations and obligations of "organic production". The main condition of $\mathrm{OF}$ is to maintain the level of soil fertility by applying only organic fertilizers (composts, other natural substrates) and plant residues, such as specially grown green manure crops and post-harvest organic crop residues.

\section{Protection of plants and crops from pests in organic farming}

In organic farming, to protect plants and crops from pests (phytophages and phytopathogens), a system of protection that meets the IFOAM requirements and does not harm other types of phytoecosystems is proposed. It is proposed to use: only resistant varieties of agricultural crops, long crop rotation with the obligatory inclusion of legumes, mixed (poly-species) crops, mechanical cultivations and agro-care of crops, the introduction of beneficial indigenous microorganisms and arthropods, induction of the suppressive potential of the soil by increasing biodiversity (genetic and functional), the use of composts and combined biological products based on suppressive, hyperparasitic and entomopathogenic bioagents (Janvier et al., 2007)

In operational protection against harmful organisms, only biological, physical and cultural methods are permissible. Weeds are eliminated using main and catch crops in the rotation, competitive crops, "cover" crops for row spacing and mechanical control. It has been shown that if winter rye is sown on the same field for 2 years in a row, many species of perennial and juvenile weeds are displaced from the agrocenosis (Van Bruggen and Finckh, 2015; Spiridonov et al., 2019). Agroplants are protected from phytophages with a variety of biological products, entomophages, and plant insecticides (Sokolov and Litvishko, 1993; Sokolov et al., 1994). Special traps with attractants, light, color and glue traps are used, both for depleting pest populations and for monitoring them. Promising wide-range field ventilator and vacuum agricultural techniques are used to collect and destroy adults of harmful insects (Tamm et al., 2015). To protect plants from pathogens, prophylactic "phytoimmunity inducers" are used, and biological products with microbial suppressors and viruses are used for operational containment.

The most important thing in organic farming is to ensure the health of the soil (soil ecosystem) with its many components, such as fertility, quality, etc. Health of soil (sol ecosystem) is a biological category reflecting the state of the dynamics of biotic component activity in the organic-mineral soil complex. This biological category is characterized by an adequate activity of biotic processes (synthesis and hydrolysis), which is consistent with the natural and climatic zone, resistance to disturbing impacts (biotic and abiotic stress factors), and completeness of cycles of biophilic elements and microbial cycles. The quality of healthy soils in agrocoenoses is consistent with standard values; their fertility is adequate for the relevant natural and climatic zone (Semenov and Van Bruggen, 2011; Semenov et al., 2011; Semenov and Đukić, 2017, 2020; Semenov and Sokolov, 2016; Semenov and Semenova, 2018). The simplest and most effective way to maintain soil health in organic farming is to follow all recommendations for ensuring soil fertility. These guidelines are fairly simple but effective. It is not recommended to leave the soil fallow (that is, without plants); it is necessary to use only gentle mechanical, mainly surface tillage. Indispensable conditions for maintaining soil health in organic farming are crop rotations, sowing of symbiotrophic crops, which ensure the development of nitrogen-fixing microorganisms, and suppressor crops, which suppress the development of root rot and other soil diseases. It is promising to use mixed, multi-species and poly-varietal crops, "mosaic of varieties" (differing in resistance to phytopathogens and phytophages). Water extracts from plants, composts and "suppressive soils" can also be applied. Selected natural microbial communities (MS) obtained from soils with stable suppressive properties are effective for use. For the selection of MCs with suppressive properties, a continuous flow-through design has already been developed, which ensures the production of MC suppressors as applied to specific phytopathogens (Semenov et al., 2001).

\section{Oligotrophication of agroecosystem as the method of soil health improvement and maintenance}

Oligotrophication of soil ecosystems, as a theoretical and experimental concept, is undergoing the stage of comprehension. The idea of oligotrophication of soil ecosystems has evolved from two concepts in microbial ecology, the concept of oligotrophic microorganisms and the soil health concept (Doran et al., 1996; Doran and Zeiss, 2000; Van Bruggen and Semenov, 2000; O'Neill et al., 1986; Semenov, 1991). The proposed scientific and practical technology of soil oligotrophication as a model for the formation of healthy and stress-resistant agroecosystems will help to ensure minimal risks of phyto- and enteropathogen circulation and a significant reduction in greenhouse gas emissions.

Let us note the main provisions of this theoretical and experimental concept in comparison with the characteristics inherent in eutrophic ecosystems. In contrast to eutrophic aquatic ecosystems, eutrophic soil ecosystems should include soils containing a large, even excessive amount of biophilic elements in readily available forms. In an oligotrophic soil ecosystem, the concentrations of readily available forms of biophilic elements ( $\mathrm{C}, \mathrm{N}, \mathrm{P}, \mathrm{K}$, etc.) are low, while their total content as well as the diversity and abundance of biota are relatively high as a result of K-selection. Changes in the number of microorganisms and concentrations of their metabolites after disturbing effects on the oligotrophic soil ecosystem remain moderate (Semenov and Bubnov, 2013).

Eutrophic soils, as a rule, are rich in biophilic elements, but are characterized by a "narrow" ratio of their total values to their available contents and may have a high number of microorganisms. Eutrophic soils are inferior to oligotrophic soils in biodiversity. 
Eutrophic soils react to stress in an explosive manner due to the low buffering capacity of the microbial community selected as $r$-selection in such soil ecosystems. In this regard, oligotrophic soil ecosystems can be considered as more stable and healthy ecosystems. In oligotrophic soil systems, the functioning cycles of biophilic elements are "conditionally closed" and are more balanced in terms of their efficiency. As already noted, oligotrophic systems have not only a high level of biodiversity, but also a higher abundance of saprotrophic symbiotic microorganisms. Saprotrophs, dominating in oligotrophic ecosystems, contribute to the displacement of phyto- and enteropathogenic microorganisms due to their abundance and diversity, since all microzones of SE are densely occupied, and the concentration of readily available substances in these econiches is low. The advantages of oligotrophic agroecosystems also lie in the fact that, due to low concentrations of readily available elements, they do not pollute adjacent soil and aquatic ecosystems with nitrates, phosphates, pesticides, and the atmosphere with greenhouse gases. Fertilizers in oligotrophic SE will be used with increased efficiency (Đukić et al., 2020). Taking into account the listed provisions and properties, oligotrophic agroecosystems are generally more environmentally friendly and economically profitable due to the reduction in irreplaceable energy costs during their operation (Semenov et al., 2011). The considered method can (and should!) be used to maintain and improve any SE.

To translate the listed advantages of oligotrophic and oligotrophic soil ecosystems into practice, of course, further research is needed to clarify the interaction of such ecosystems with phyto-agroecosystems, the effect of oligotrophication on indicators of the quality of agricultural soils, their fertility, suppressive activity of SE, etc.

\section{Conclusions}

At the present stage of societal development, organic farming has turned into a special, scienceintensive technological system of farming, environmentally friendly in relation to the general soil ecosystem. At the same time, the organic farming system is socially and environmentally responsible not only for the production of normatively safe crop products, but also for the disposal of waste, i.e. there is a cyclization of processes, production, consumption and disposal of consumer products with a return to the ecosystem. The traditional characteristics of a soil ecosystem - soil quality and soil fertility - must be replenished with a new category - soil health, and given the level of the most important, general soil characteristic. It is proposed to consider soil quality and fertility as components of soil health. It is quite obvious that soil quality concept is mainly a physicochemical characteristic of a soil ecosystem, and fertility is its consumer component. Soil health is a scientific, integral characteristic that combines the biological and ecological properties of this unique natural product - soil. The soil health category emphasizes the biological essence of soil origin as an irreplaceable, unique natural ecosystem. Only in healthy SE and organic farming can such natural phenomena as symbiosis, commensalism, cooperation, syntrophy and, of course, competition be realized.
Organic farming really corresponds to the concept and meaning of sustainable development of agriculture, agricultural production and environmental protection. It relies on self-sufficiency and cyclization of substances, on minimizing the consumption of irreplaceable energy sources. In organic farming, protection against harmful organisms is based primarily on preventive and biological methods, on competition, biocontrol, gentle mechanical treatments, and not on the total extermination of harmful species. Organic farming, as it were, constantly supports "perpetual motion", that is, the eternal movement of substances and their reproduction. The technological elements of OF are used in pesticide-free technologies for the production of high-quality elite seeds of cultivated plants, especially valuable crops (in recreational and water protection zones), raw materials for the production of medical products, baby food and medicines.

\section{Acknowledgment}

The research was carried out as part of the Scientific Project of the State Order of the Government of the Russian Federation to Lomonosov Moscow State University No. 121032300094-7.

\section{Declaration of competing interest} interest.

The Authors declare that there is no conflict of

\section{References}

Buyer, J.S., Kaufman, D.D. (1996). Microbial diversity in the rhizosphere of corn grown under conventional and lowinput systems. Applied Soil Ecology, 5, 21-27.

Clark, M.S., Horwath, W.R., Shennan, C., Scow, K.M., Lanini, W.T., Ferris, H. (1999). Nitrogen, weeds and water as yield-limiting factors in conventional, low-input, and organic tomato systems. Agriculture, Ecosystems and Environment, 73, 257-270.

Doran, J.W., Sarrantonio, M., Liebig, M.A. (1996). Soil health and sustainability. Advanced Agronomy, 56, 1-54.

Doran, J.W., Zeiss, M.R. (2000). Soil health and sustainability: managing the biotic component of soil quality. Applied Soil Ecology, 15, 3-11.

Drury, C.F., Stone, J.A., Findlay, W.I. (1991). Microbial biomass and soil structure associated with corn, grass and legumes. Soil Science Society of America Journal, 55, 805811.

Đukić, D.A., Semenov, A.M., Lutovac, M.V., Mandić, L.G., Iutinska, G.A., Podgorski, V.S. (2020). Soil ecosystems contamination and cleaning "SAJNOS” DOO, Novi Sad Novi Sad. Serbia, 628 p. (In Serbian).

Ferris, H., Tuomisto, H. (2015). Unearthing the role of biological diversity in soil health. Soil Biology and Biochemistry, 85, 101-109.

Franzluebbers, A.J., Hons, F.M., Zuberer, D.A. (1995). Soil organic carbon, microbial biomass and mineralisable carbon and nitrogen in sorghum. Soil Science Society of America Journal, 59, 460-466.

Garbeva, P., Van Veen, J.A., Van Elsas, J.D. (2004). Microbial diversity in soil: selection of microbial populations by plant and soil type and implications for disease suppressiveness. Annual Review of Phytopathology, 42, 243-270.

Glinushkin, A.P., Sokolov, M.S., Toropova, E.Yu. (2016). Healthy soil and its reproduction in alternative farming systems. Phytosanitary and hygienic requirements for healthy soil. Agrorus, 238 p. (In Russ). 
Janvier, C., Villeneuve, F., Alabouvette, C., Edel-Hermann, V., Mateille, T., Steinberg, C. (2007). Soil health through soil disease suppression: Which strategy from descriptors to indicators? Soil Biology and Biochemistry, 39, 1-23.

Maeder, P., Fließbach, A., Dubois, D., Gunst, L., Fried, P., Niggli, U. (2002). Soil Fertility and Biodiversity in Organic Farming. Science, 296 (5573), 1694-1697.

O'Neill, R.V., De Angeles, D.L., Waide, J.B., Allen, T.F.H. (1986). A hierarchical concept of ecosystems. Princeton: Princeton Univ. Press, 253 p.

Organic regulations. URL: http://www.ifoam-eu.org/en/whatwe-do/organic-regulations (Used: 30.03.2016).

Semenov, A.M. (1991). Physiological bases of oligotrophy of microorganisms and the concept of microbial community. Microbial Ecology, 22, 239-247.

Semenov, A.M., Bubnov, I.A. (2013).Determination of the soil health parameter when using various disturbing effects. Problems of agrochemistry and ecology, 3, 23-30. (In Russ.)

Semenov, A.M., Đukić, D.A. (2020). The role of microbial communities in soil formation and soil ecosystem health. Paleontological Journal, 54(8), 35-44.

Semenov, A.M., Đukić, D.A. (2017). Soil health - ecosystem health: from problem identification to diagnosis and treatment. Acta Agriculturae Serbica, 22(43), 103-111.

Semenov, A.M., Semenova, E.V. (2018). Soil as a biological system and its new category - health. Biology Bulletin Reviews, 8(6), 463-471.

Semenov, A.M., Sokolov, M.S. (2016). The concept of soil health: fundamental and applied aspects of evaluation criteria. Agrokhimiya, 1, 3-16. (In Russ.)

Semenov, A.M., Van Bruggen A.H.C. (2011). Parameters of healthy soil. Agro XXI, 1-3, 8-10. (In Russ.)

Semenov, A.M., Van Bruggen, A.H.K., Semenova, E.V., Gorodetskaya, L.V. (2001). System for continuous selection of microbial communities with biocontrolling properties of root pathogens. Abstracts of the All-Russian conference "Agricultural microbiology in the XIX-XXI centuries". St. Petersburg, 73-74. (In Russ.)

Semenov, A.M., Semenov, V.M., Van Bruggen, A.H.C. (2011). Diagnostics of health and quality of soil. Agrokhimiya, 12, 4-20. (In Russ.)
Schjønning, P., Elmholdt, S., Munkholm, L.J., Debosz, K. (2002). Soil quality aspects of humid sandy loams as influenced by organic and conventional long-term management. Agriculture, Ecosystems and Environment, 88, 195-214.

Sokolov, M.S., Glinushkin, A.P., Toropova, E.Yu., Borovaya, V.P., Bugaeva, L.N. (2015). Healthy soil - phytosanitary basis for pesticide-free crop production. RJOAS, 12(48), 3-9.

Sokolov, M.S., Litvishko, E.V. (1993). Biological plant protection in the USA. Plant protection, 11, 18-20. (In Russ.)

Sokolov, M.S., Monastyrsky, O.A., Pikushova, E.A. (1994). Greening plant protection. Pushchino: ONTI NCBI RAN, 322-336. (In Russ.)

Sustainable Development Strategy (2002).

Spiridonov, Yu.Ya., Sokolov, M.S., Glinushkin, A.P., Karakotov, S.D., Korshunov, A.V., Toropova, E.Yu., Saraev, P.V., Semenov, A.M., Semenov, V.M., Nikitin, N.V., Kalinichenko, V.P., Lysenko, Yu.N. (2019). Adaptively integrated crop protection. Printed City. Moscow. 628 p. (in Russ.)

Tamm, L., Willer, H., Van Bruggen, A.H.C. (2015). Organic perennial crop production. In Plant Diseases and Their Management in Organic Agriculture. Ed. by Finckh M.R., van Bruggen A.H.C., Tamm L. APS PRESS, $424 \mathrm{p}$.

Van Bruggen, A.H.C., Semenov, A.M. (2000). In search of biological indicators for soil health and disease suppression Applied Soil Ecology, 15, 13-24.

Van Bruggen, A.H.C, Semenov, A.M., Van Diepeningen, A.D., De Vos, O.J., Blok, W.J. (2006). Relation between soil health, wave-like fluctuations in microbial populations, and soilborne plant disease management. European Journal of Plant Pathology, 115, 105-122.

Van Bruggen, A.H.C., Semenov, A.M. (2015). Soil health and soilborne diseases in organic agriculture. In "Plant Diseases and Their Management in Organic Agriculture". Ed. by Finckh M.R., van Bruggen A.H.C. and Tamm L. APS PRESS, $424 \mathrm{p}$.

Van Bruggen, A.H.C, Finckh, M.R. (2015). General principles of organic production. In "Plant Diseases and Their Management in Organic Agriculture ", Ed. by Finckh M.R., van Bruggen A.H.C., Tamm L. APS PRESS, 424 p.

Veličković, M., Golijan, J., Popović, A. (2016). Biodiversity and organic agriculture. Acta Agriculturae Serbica, 21(42), 123-134. 